\title{
The Politics of Ageing in America ${ }^{2}$
}

\author{
CARROLL L. ESTES*
}

\section{$A B S T R A C T$}

This paper discusses the politics of ageing in the US within a political economy framework. Four forces are shaping US policy: austerity, federalism, deregulation, and the medical-industrial complex. Two major trends in the development of policy are the commodification of the aged and their needs and a class basis for the distribution of benefits, differentiating the deserving elderly from the undeserving elderly. Ideologies of individualism, self-help, privatisation, and procompetition are being used to delegitimate public programmes and to reduce expectations about what government can and should do to ameliorate social problems.

Recent policy is characterised not only by a reduction of federal funds for domestic social spending, but also a restructuring of the community care delivery system as it operates in the private, non-profit sector of the economy. The emergent processes of this restructuring, e.g., targeting of services based on ability to pay and individual characteristics, medicalisation, and absorption of non-profit agencies by for-profits are discussed. These policies and the consequences that flow from them are viewed in light of the search for new sources of capital investment in the domestic markets. This analysis raises important political questions concerning the transformation of relations between the state and the non-profit sector.

\section{Introduction}

The central challenge of a political economy of ageing is to move beyond a critique of conventional gerontology, to develop an understanding of

$\dagger$ Text of a plenary session paper presented at the annual Conference of the British Society of Gerontology University of Keele, Keele, Staffordshire, England on 28 September, 1985 .

* Professor and Chair, Department of Social and Behavioral Sciences, School of Nursing, and Director, Institute for Health and Aging, University of California, San Francisco, CA 94143. 
the character and significance of variations in the treatment of the aged, and to relate these to polity, economy and society in advanced capitalism. ${ }^{1}$ This requires an examination of society's treatment of the aged in the context of the national and world economy, the role of the state, conditions of the labour market, and class, race, gender and age divisions in society. At base, this requires examination of the relationship of capitalism to ageing. ${ }^{2}$ It also begins with the proposition that the status and resources of the elderly, and even the experience of old age itself, are conditioned by one's location in the social structure and the local to global economic and social factors that shape that location. ${ }^{3}$

The themes that characterise and frame contemporary US debate over policy for the ageing are inextricably linked to the major issues of the economy, and the respective roles of the state, the for-profit (market) and the not-for-profit sectors. Of growing importance is the struggle between the rights of citizens versus the rights of property, ${ }^{4}$ or in $\mathrm{O}^{\prime}$ Connor's ${ }^{5}$ terms, the struggle between the citizen state and the class state.

\section{Trends in public policy}

The decade of the 1980 is characterised by economic uncertainty and political ambiguity regarding the direction of US public policy for the elderly. Analysis of policy trends during the past decade suggests that four forces have been and will continue to be central in shaping US policy: austerity, federalism, deregulation and the medical-industrial complex.

\section{Austerity}

Inflation, recession, unemployment, tax cuts for the wealthy, reductions in social spending, increases in defence spending, high interest rates, and other fiscal and monetary policies portray in vivid economic terms the impact of austerity and its political processing.

Austerity is both objective and subjective. The objective basis of austerity is a worldwide economic crisis that has resulted in less 'slack' in the economic system and increased efforts to foster the conditions for renewed capital expansion in O'Connor's ${ }^{6}$ terms, it is an 'accumulation crisis'. A noteworthy result in the US, beginning about 1978 and continuing to the present, has been the generation of an objective fiscal crisis at both state and local levels resulting from a combination of successful and conservatively organised state taxpayer revolts, federal budget cuts, and a recession engineered in the face of a profit squeeze, 
increased corporate bankruptcies, and decreased competitiveness of large industrial sectors. Although these impacts have not been equally felt in the different states, states and localities are experiencing serious financing problems for their increasing programme responsibility.

The subjective basis of austerity lies in the socially constructed notion that federal spending on the elderly and on the poor is the cause of the problems of the US economy. Blaming the ageing obscures the origins of problems stemming from the capitalist economic system and the subsequent political choices that are made - choices that dramatically increased the federal deficit (i.e. the $\$ 75^{\circ}$ billion tax cut; the $57 \%$ increase in expenditures for defence; the trebling of US interest on the debt, from $\$ 5^{\circ}$ to $\$ 15^{0}$ billion annually, all since 1981 ) as well as the continuing flight of US capital around the globe in search of new investments and profits.

That such 'social constructions' of reality become a force of their own is evident in the current ideology that austerity (now coined as 'deficit reduction') and not social need is to be the determinant of social policy. Needless to say, both symbolic and material consequences flow from such definitions. ${ }^{7}$

It must be observed here that the content of the defined crises that necessitate austerity, as well as the remedies invoked are not so much related to the objective facts of the situation as to the capacity of strategically located groups and classes to press their views into public consciousness and law. In other words, the resulting sacrifices will be apportioned according to inequalities in the power to define and design the 'solutions'. Thus, class, race and gender will tend to differentiate the distribution of the consequences of the sacrifices to be made.

\section{Federalism}

Federalism denotes the relationships among different levels of government, raising the fundamental question of politics: Who will decide? In the 1970s, President Nixon introduced new federalism policies designed to increase state and local responsibility, to reduce the federal role, and to stem the proliferation of categorical programmes in the rg6os. A number of such categorical programmes had developed in health and ageing services. Under the Reagan Administration, new federalism continues to be vigorously pursued through block grants, the abolition of federal revenue sharing and other federal budget reductions to the states and localities under the rhetoric of returning more autonomy and discretion to the states. In its most extreme form, new federalism challenges the idea that there is a national responsibility for meeting basic human needs in health, income, housing or welfare. 
Two fundamental questions concern contemporary new federalism and the decentralisation fostered by it: First, do state and local governments have the fiscal and other capacity to deal effectively with their traditional responsibilities and to assume greater responsibility for programmes in welfare, education, transportation, social services and health, particularly when the broad economic policies that necessitate these programmes do not lie in the hands of decentralised governments, but are the result of federal policies and actions? Second, how uniformly committed can (or will) states be to equity, social justice, and racial equality, particularly under conditions of austerity. ${ }^{8,9}$

\section{Deregulation}

A hallmark of Reagan Administration policy is deregulation, both in bureaucratic practice and ideology. Its effects are evident in the new discretion that state governments have received to cost-cut, to relax (i.e. tighten) eligibility, to eliminate their matching for federal funds, to eliminate services, and to relax affirmative action and civil rights requirements. The most profound impact of deregulation is the eradication of federal restrictions against the entry of proprietary for-profit firms in many governmentally financed programmes that previously barred such firms, and the efforts to promote 'market competition' that have accompanied these deregulatory moves.

\section{Medical-industrial complex}

Finally, and of growing importance to the elderly, is what nas come to be known as the medical-industrial complex, and particularly the growing proprietary ownership of hospitals, of systems of medical care delivery, and of other businesses related to medical goods and services. ${ }^{10,11}$

With US personal health care expenditures approximating $\$ 400$ billion per year (almost I $\%$ of the gross national product), the importance of the for-profit markets in medical care is obvious. Intensified by the pro-competition and deregulation policies noted above, a perennial issue in the politics of US health care has been unearthed - whether health care should be provided as a 'market good' (i.e. purchased as a commodity primarily by those who can afford to pay) or whether health care should be treated as a 'merit good' (i.e. as a right or collective good that should be available regardless of ability to pay). ${ }^{12}$

The medicalisation of ageing via a robust medical - industrial complex is entirely consistent with the predominant US image of ageing as a 
process of individual physiological and biological decline that requires biomedical research and medical interventions for its treatment. Consistent with the liberal philosophical emphasis on individual responsibility, US public policy has been predicted largely on a conception of ageing as an individual problem (and thus as an 'apolitical' problem of inexorable biological decline). Public policy has emphasised treating individuals via services with a medical character, placing power largely in the hands of service providers who receive reimbursement, ${ }^{13}$ and raising questions of socially generated dependency. ${ }^{14}$

\section{Separatism}

The resulting policies also have the core characteristic of being largely separatist in nature - that is, of separating the aged from other groups in US society on the basis of their special need. In 1979, I described the consequence of this problem formulation and policy prescription as the creation of an 'ageing enterprise' or programmes, organisations, and professionals to serve the elderly. The concept of an 'enterprise' was employed in order to call attention to how the aged and their needs are processed and treated as a commodity, and to the fact that the age-segregated policies that fuel the enterprise are, I believe, socially divisive solutions, in contrast to those policies that do not single out and separate the aged from the rest of society. ${ }^{15}$

In addition, current US old age policy reflects a two-class system of welfare where benefits are distributed on the basis of legitimacy ${ }^{16}$ rather than on the basis of need. Old age neither levels nor diminishes social class distinctions. As is the case in the $\mathrm{UK}$, resources in old age are largely determined by lifetime conditions and labour force participation established prior to retirement age. ${ }^{17}$ In the US, income, health and social service policies reflect different classes of 'deserving-ness' in old age. ${ }^{18}$ Deservingness in old age is predicated upon the principle of differential rewards for differential lifetime achievements in the labour market (see Table I).

The 'deserving' (non-poor) aged have the resources to permit access to public and private services without the necessity of government intervention. They also receive a disproportionate share of the benefits of the largest federal programs for the aged (e.g. Social Security, Medicare, and retirement tax credits), estimated at $\$ 43$ billion in $1982 .{ }^{19}$ Most social service policies tend to favour the 'newly poor' in old age, largely because they are thought of as both deserving and threatened with impoverishment in later life. These services (e.g. congregate meals and Older Americans Act services) were designed to assist this potentially downwardly mobile group to maintain their 
TA B LE I. Class basis of ageing policies

\begin{tabular}{|c|c|}
\hline $\begin{array}{l}\text { Deserving elderly } \\
\text { ( I Federal policy) }\end{array}$ & $\begin{array}{l}\text { Undeserving elderly } \\
\text { (50 State variable policies) }\end{array}$ \\
\hline \multicolumn{2}{|c|}{$\begin{array}{l}\text { INCOME } \\
\text { Social Security (SS) }\end{array}$} \\
\hline $\begin{array}{l}\text { Regressive taxation - No SS } \\
\text { Tax after } \$ 35,700 \text { salary level } \\
\text { Private pensions } \\
\text { Tax policy } \\
\text { Individual Retirement Accounts } \\
\text { (IRA) } \\
\text { Tax Credits - Economic } \\
\text { Economic recovery } \\
\text { Tax Act of } 1981\end{array}$ & $\begin{array}{l}\text { Minimum Social Security benefit } \\
\text { eliminated for all future eligibles } \\
\text { Unlikely to supplement with } \\
\text { private pensions } \\
\text { Supplemental Security } \\
\text { Income (SSI)* } \\
\text { Payment levels below poverty } \\
\text { Means-tested for the poor only }\end{array}$ \\
\hline \multicolumn{2}{|c|}{$\begin{array}{l}\text { HEALTH } \\
\text { Medicare programme }\end{array}$} \\
\hline $\begin{array}{l}\text { Expenditures are high } \\
\text { for this Group } \\
\text { Greater capacity to pay } \\
\text { deductibles and } \\
\text { co-payments }\end{array}$ & $\begin{array}{l}\text { Lower access to physicians } \\
\text { and hospitals for } \\
\text { blacks and other minorities } \\
\text { and poor } \\
\text { Medicaid programme* } \\
\text { Means-tested for the poor only - } \\
\text { approx. 50\% of persons below } \\
\text { poverty not covered }\end{array}$ \\
\hline \multirow[t]{2}{*}{$\begin{array}{l}\text { More capacity to afford } \\
\text { coverage }\end{array}$} & $\begin{array}{l}\text { insurance } \\
\text { Little or no capacity to purchase } \\
\text { coverage }\end{array}$ \\
\hline & $\begin{array}{l}\text { SER VICES } \\
\text { es block grant* } \\
\text { f the Social Security Act) } \\
\text { No federally mandated priority } \\
\text { to low-income eligibles }\end{array}$ \\
\hline \multicolumn{2}{|c|}{$\begin{array}{l}\text { Older Americans Act* } \\
\text { No federally mandated priority }\end{array}$} \\
\hline
\end{tabular}

* State variable policies emerge primarily from state-federal programmes in which states have much discretion over eligibility and scope of available services. State discretionary programmes are fiscally vulnerable, uncertain, unstable, and highly vulnerable to swings in state level political and economic factors.

lifestyles, rather than to provide the more crucial life-support services (e.g. income or housing) most needed by the undeserving aged. Those 'undeserving' life-long poor aged are assisted largely through increasingly stringent and inadequate income-maintenance policies such as Supplemental Security Income (SSI), which has different eligibility and payment standards across the states; and through Medicaid, the medical-welfare programme for the extremely poor 
(which is highly variable from state to state and so stringent that only $46 \%$ of the below-poverty population is eligible. ${ }^{20}$

In the past, those individuals who had been casually (or sporadically) employed or who had very low lifetime earnings covered by Social Security (mainly women and minorities) were entitled to a minimum Social Security benefit that guaranteed a basic monthly payment of $\$ 122 .{ }^{21}$ However, the Reagan Administration eliminated even this meagre minimum benefit for new retirees after January, $198 \mathrm{I}$, successfully removing these 'undeserving' aged from receiving Social Security trust funds that they had not earned.

In sum, policies that deal with the 'undeserving' aged are 'state discretionary policies' carried out by 50 states with programme eligibility and benefits largely dependent upon the states' variable political willingness and fiscal capacity. These programmes are both economically and politically vulnerable and more variable than uniform federal programmes. Thus, the most economically disadvantaged aged (the undeserving aged) do not have the security of stable, uniformly administered federal policies (like Social Security and Medicare) that apply to those considered more deserving.

Even Medicare, the US national health programme for its ageing, benefits 'the deserving' more than the 'undeserving'. First, research has shown that there are significant benefit inequities based on income, race and region. For example, in the southern region of the United States, where $56 \%$ of the nation's aged non-whites reside, the disparities between benefits received by white and non-white Medicare beneficiaries persist. ${ }^{22}$ These inequities are noteworthy when controlling for illness, since the lower income and minorities tend to experience disproportionately ill health. Second, the higher-income aged can better afford the rapidly rising co-payments and deductibles increased since $198 \mathrm{I}$ to discourage service utilisation. ${ }^{23}$ Third, the well-off elderly can supplement these benefits by purchasing private health insurance, in contrast to the lower income (undeserving) aged who cannot afford to do so. Fourth, the flat-rate co-payments and deductibles (e.g. currently $\$ 400$ for the first day of hospital care in a year regardless of income - and rising to $\$ 492$ on I January 1986 ) and other out-of-pocket costs are particularly onerous since they exceeded $\$ 1,500$ per capita in $1984^{24}$ Estimates by the Congressional Budget Office are that in 1984 , those with incomes below $\$ 5,000$ per annum would pay close to $20 \%$, while those with incomes above $\$ 58$,ooo would pay only about i $\%$ for their out-of-pocket medical costs. ${ }^{25}$

The lesson is clear. For all of the public veneration of ageing, it is not federal policy to formally address the needs of the most disadvantaged 
with a national policy that is uniform for all low-income - either aged or non-aged across the country. Thus, decisions about services to the poor are located at the state and local level, precisely where pressures to control social expenses are greatest and where it is most difficult to increase corporate taxes for fear of business threats to relocate. (This phenomenon has been described as the structural segregation of policy by Friedland, Alford and Piven. ${ }^{26}$ )

\section{Major current trends}

An important effort in the US public policy debate has been the attempt to 'de-legitimate' the ageing by reinstating the dominance of ideologies of individualism and self-help to reaffirm the belief that individuals create their own conditions and opportunities and thus are to blame for their predicament. Attacks on Social Security and Medicare share the characteristic of blaming the elderly for the problems of the economy.

The blame for the 'impending bankruptcy' of Social Security (of course, an impossibility with publicly financed programmes) has not been placed on the fiscal, monetary and other factors that produced the recession, nor on other pressures for early retirement such as unemployment (that reduce payments into Social Security) and inflation (that increase payments out by Social Security through cost of living adjustments, COLA's). ${ }^{27}$ Instead, Social Security's problems have been portrayed as the product of 'mistaken' generosity in domestic programmes, of demographic ageing, and the fault of those choosing to retire early - ignoring health status, age discrimination, and structural unemployment problems that significantly contribute to early retirement. ${ }^{28}$

Probably most important in stimulating the socially produced Social Security crisis was the need for new sources of investment in the context of profitability problems of corporate America. ${ }^{29}$ Conservative economists argue that Social Security reduces public reliance on the market; it increases individual dependency on government; and it reduces incentives for personal savings that are needed in the private sector for capital investment and economic growth. ${ }^{30}$ The needs of private capital have fuelled the political attempts to dramatically weaken US commitment to its Social Security programme and to privatise this bedrock programme that keeps an estimated $60 \%$ of the elderly out of poverty.

Although the re-privatisation scheme for Social Security failed, big tax subsidies were enacted to encourage private saving through Individual Retirement Accounts (IRAs), imposing: (I) the definition of 
Social Security as an unstable 'flim-flam' public programme; (2) constraints against raising future Social Security payments to adequate levels (because the middle class can now privately buy their increments in old age income through IRAs); (3) a new source of investment capital to banks and stockbrokers who invest IRAs; and (4) a continuance of a class-biased old age income policy where those able to afford a $\$ 2,000$ a year tax-free IRA investment will be subsidised by the rest of us, while those dependent on public programmes (e.g. women and minorities) will fall further behind.

A similar scenario is being played out regarding Medicare-a programme that pays only $44 \%$ of the elderly's medical bill and that does not cover physical exams, out-of-hospital drugs, dental or eye care, or custodial in-home institutional long-term care. As socially 'constructed' and 'produced' by powerful opinion-makers in the US, the dual symbols of a Medicare hospital trust fund ban' ruptcy ${ }^{31}$ and the resurgent idealogies of individualism and market competition support the tendency to blame the elderly for Medicare's problems (for using too many services and, of course, for living too long). The solutions promoted under this construction of reality are the corporatisation and the further (or complete) privatisation of medical care.

In addition to significant increases in the amount of patient costsharing already described, a new reimbursement scheme for hospitals has been introduced under Medicare to control costs. Under this scheme, hospitals are paid on a prospective, fixed price basis per diagnosis (DRGs), creating major incentives for hospitals to reduce in-patient hospital days and encouraging the discharge of elders 'sicker and quicker'. In fact, the average length of hospital stay for those 65 and older declined $7.5 \%$ in 1984 , attributed largely to this new policy. It also appears to be generating an accelerated demand on the community-based service delivery system and on women caretakers. ${ }^{32}$ In addition, deregulation and tax laws are encouraging the entry of proprietaries into medical markets (both hospital and home health).

Among the 'solutions' offered, but not yet adopted, for Medicare's problems are: ( 1 ) increasing the age of eligibility for Medicare to 67 years of age (in spite of the fact that those poor and minorities with higher rates of chronic illness and lower life expectancy would be severely disadvantaged); (2) making Medicare a voucher programme, giving elders vouchers to privately purchase their own medical care, to hopefully force them to behave rationally in a (theoretically competitive) market by purchasing the cheapest private insurance (probably underinsuring themselves and paying higher costs out of pocket); and (3) instituting a completely private medical insurance system through 'Health Bank Individual Retirement Accounts', or IRAs. The latter 
two approaches (medical vouchers and IRAs) are likely to encourage the now familiar phenomena of 'dumping' the sickest, most costly elderly, and 'creaming' (enrolling) those who are most healthy and 'profitable'. Not only is the government not likely to save costs under these schemes, costs could actually increase significantly since the state will probably have to pay for the highest cost, sickest elderly under either programme.

Health care advocates and the elderly are caught between the dual interests of government and the for-profit sector. Each is attempting to constrain and reduce its own direct expenditures, while neither is seeking to assure or enhance access to needed services. Simultaneously, physicians, hospitals and proprietary corporations are seeking to ensure the availability of a growing and highly profitable private market in medical care.

Regrettably, the hope that medical cost containment pressures might result in the financing of alternatives to costly acute hospital care has not come to pass. In spite of much rhetoric calling for chronic care and social supportive services, paradoxically, the US appears to be moving further away from - not closer to - that heralded continuum of care. Our research is documenting several potentially ominous trends. First, since 198 I there has been a significant reduction of federal funding for non-hospital community social, health and mental health services, and particularly to non-profit sector agencies delivering these services. ${ }^{33}$ Second, a restructuring of the community care delivery system appears to be resulting from recent federal policies that are promoting:

(a) The recommodification and privatisation of the most profitable areas of human services (e.g. expansion of proprietaries into areas of medical and social services) through deregulation and other policies (e.g. tax subsidies) favouring their entry.

(b) The de-legitimation of both non-profit sector and state sector services through idealogical attacks on their efficiency and 'unfair competition'. This is important since, historically, both the state and non-profit sectors have served the low-income population.

(c) The expansion and diversification of organisational forms (auspice, tax status) of agencies that deliver community services, including their vertical and horizontal integration. ${ }^{34}$

(d) The absorption of non-profit community agencies by for-profit entities.

(e) The medicalisation of social services due largely to US Medicare and Medicaid reimbursement schemes, and the inherent advantages of medical over social services in terms of publically financed reimbursement (and profitability). 
$(f)$ The further fragmentation of services ("unbundled' services where primarily those single services are offered by providers that are reimbursed by the state while other important services are dropped). The result is a change in the scope and nature of the services that are available.

( $g$ ) The polarisation of services in favour of the 'old old' versus the 'young old' frail versus non-frail, and a class-linked polarisation between those agencies serving clients who can afford to pay privately versus those serving clients who cannot afford to pay for their services.

(h) A growing disparity between medical services provided in the home and social services provided in the community. With hospital cost containment, the 'newest institution' is becoming the home, where extremely sick elders receive minimal medically oriented services for a finite time period.

(i) A process of informalisation, wherein functions of hospitals and community agencies are being transferred out of the formal delivery system and into the family and home (mainly to women).

Political economists have described the search for profits and ever new sources of capital investment as a driving force of capitalism. ${ }^{35}$ What the austerity of the 1980 s shows is that, in the US the search for new sources of capital investment, new markets and profits is not confined to the pursuit of foreign markets or to the internationalisation of capital. There is a re-invigorated pursuit of such potential sources of profitability within US borders itself via the corporatisation of virtually every aspect of medical care and the profitable areas of social care (e.g. meals on wheels and in-home medical services).

Given the contemporary social, economic and political crises of the capitalist system, there is heightened debate among political theorists: Is a welfare state compatible with, or necessary for, capital accumulation? (A long line of welfare state theorists have argued this one.) How compatible or essential is the not-for-profit voluntary sector with the needs of capital at this historical juncture and under the current ideology and practice of austerity?

It will be important to distinguish between those functions that the state and the non-profit sectors perform (separately or in combination) in the provision of old age benefits, which various segments of capital need but cannot perform themselves and those activities than in some way 'infringe' on capital. Equally important questions concern how social movements, class and other political constellations will obstruct (or facilitate) the transformations of the state and the non-profit sectors that appear to be underway, and what these transformations will mean for the existing patterns of inequality. 


\section{The future of ageing}

The future of ageing in the US will be profoundly shaped and altered by the economic, social and political crises of capitalism and the ensuing struggles around them.

A deeply political process of crisis naming, blaming, sorting and shifting has occurred. For the ageing, the potential implications include greater social inequalities; the private purchase of more and more needed health and social care by individuals rather than entitlement to it; increased corporatisation of services; the medicalisation and disaggregation ('unbundling') of services to increase profitability; and the transference of a growing number of public responsibilities to private families (informalisation).

Two US observers have raised central and basic questions: Kuttner ${ }^{36}$ asks: What are the limits of the welfare state in countering the inequalities of the laissez-faire capitalist system? While S. M. Miller calls us to a broader outlook, saying that:

Welfare state adherents have to address the issues of macroeconomic policy and economic structure so that the original distribution of income is less unequal, reducing the task confronting the welfare state. ${ }^{37}$

\section{Conclusion}

The challenge for students of social gerontology is to meet the promise of a political economy of ageing - to do the serious intellectual work that will compel others to understand and act, based on the knowledge that ageing is part of the whole; that is, part of the capitalist economy and society within which redundancy is declared and imposed and within which power struggles are waged and won that shape the ageing experience. In the process, we must learn much more about the power of the human agency to resist and to de-construct, as well as construct reality - and particularly such 'realities' as fiscal crisis and the notions of who is to blame and who is to sacrifice.

For those working for social change, two immediate challenges are presented. One raises a question of the generations and the other raises a question of class. There is a need for ageing interest groups, organisations and professionals to identify and work on the basis of the commonalities existing between the socially and structurally induced problems of the aged and non-aged. For example, in the US a health 'system' that costs $\$ 400$ billion; that is I I \% of the gross national product (GNP); that produces more than $\$ 6$ o billion annually in 
private profit; that is $42 \%$ government financed; that does not cover (or insure) more than 35 million Americans (almost 20\%) for their health care, including 389,00o elders; and that costs older Americans $19-27 \%$ of their annual income (not covered by Medicare), calls for a major reorientation and re-structuring based on an intergenerational agenda. In the UK the preservation of the national health service against its privatisation and the erosion of public entitlement is a comparable issue. The class question concerns whether (and how) the middle-class aged (who are highly dependent on the state benefits of Social Security, Medicare, and tax credits) can be persuaded to understand the commonalities between their interests and the survival of a welfare state that contains re-distributive purposes benefiting their less-advantaged age cohort members.

Tough issues must be raised, including those of rights to work, to retire, to subsistence, and to health, as well as issues of tax equity (including tax subsidies to the rich and the virtual abolition of corporate taxes in the US), labour control of pension funds, ${ }^{38}$ and the unparalleled militarisation of the US economy.

\section{NOTES}

I Estes, C. L., Swan, J. and Gerard, L., Dominant and competing paradigms in gerontology: toward a political economy of ageing. Ageing and Society, 2, 2 (1982), $15 \mathrm{I}-\mathrm{I} 64$.

2 Myles, J. F., The Political Economy of Public Pensions. Little, Brown, Boston, 1984.

3 Estes, C. L., Swan, J. and Gerard, L. 1982, op. cit.

4 Myles, J. F., 1984, op. cit.

5 O'Connor, J., The Fiscal Crisis of the State. St Martin's Press, New York, 1973.

6 O'Connor, J. Accumulation Crisis. Basil Blackwell, New York, 1984.

7 Edelman, M., Political Language: Words That Succeed and Policies That Fail. Academic Press, New York, 1977.

8 Estes, C. L., The Aging Enterprise. Jossey-Bass, San Francisco, CA., 1979.

9 Estes, C. L. and Gerard, L., 'Governmental responsibility: issues of reform and federalism', in Estes, C. L. and Newcomer, R. J. (eds). Fiscal Austerity and Aging. Sage, Beverly Hills, CA, 1983 .

10 Relman, A. S., The new medical-industrial complex. The New England Journal of Medicine, 303, no. 17 (23 October 1973), 963-97o.

I Wohl, S. The Medical-Industrial Complex. Harmony, New York, 1984.

I 2 Estes, C. L., Gerard, L. E., Zones, J. and Swan, J., Political Economy, Health, and Aging. Little, Brown \& Sons, Boston, 1984 .

13 Estes, C. L., 1979, op. cit.

I4 Walker, A., Towards a political economy of old age. Ageing and Society, 1, I (1981) 73-94.

I 5 Estes, C. L., 1979, op. cil.

16 Tussing, A., 'The dual welfare system', in Horowitz, L. and Levey, C. Social Realities, Harper and Row, New York, I $97 \mathrm{I}$.

17 Walker, A., $198 \mathrm{I}$, op. cil. 
I 8 Nelson, G., Social class and public policy for the elderly. Social Service Review, 56, I (March 1982), 85-107.

I9 Nelson, G., Tax expenditures for the elderly. Gerontologist, 23,5 (October I983), $471-478$.

20 U.S. Senate, Special Committee on Aging. Developments in Aging: 1984, Vol. I. Government Printing Office, Washington, D.C., I 985.

2 I Since some estimated three million beneficiaries receive a higher monthly payment than would be payable under the regular benefit formula, critics have pointed to the alleged welfare character of the minimum social security benefit.

22 Ruther and Dobson, I981 (missing)

23 Measures already implemented to reduce Medicare costs are: (I) significant increases in patient costs for hospital care through Medicare Part A hospital deductibles (up $96 \%$ since 1981 ), for medical treatment by doctors throughout Part B annual deductibles for physician services (up $25 \%$ since $198 \mathrm{I}$ ) and the annual Part B premiums (up $62 \%$ since 1981 ), as well as new co-payments on certain equipment.

24 Davis, K., 'Health implications of aging in America'. Unpublished manuscript. Johns Hopkins University, Baltimore, 1983 .

25 U.S. Congressional Budget Office. Changing the Structure of Medicare Benefits: Issues and Options. Washington, D.C., 1983 .

26 Friedland, R., Alford, R. R. and Piven, F. F., 'The political management of the urban fiscal crises'. Paper presented at the annual meeting of the American Sociological Association, Chicago, September 1977.

27 For every one million unemployed workers, Social Security loses \$100 million in contributions per month, and each $1 \%$ of inflation is estimated to cost Social Security $\$ 1.5$ billion annually.

28 Estes, C. L., Social security: the social construction of a crisis. Milbank Memorial Fund Quarterly/Health and Society, 6r,3 ( 1983$), 445^{-461}$.

29 Myles, J. F., 'Population aging and the elderly', in Forcese, D. and Richer, S. (eds). Social Issues: Sociological Views of Canada. Prentice-Hall, Ontario 1982.

3o Rahn, R. W. and Simonson, K. D., 'Tax policy for retirement programmes'. In Retirement Income: Who Gets How Much and Who Pays? (National Journal Issues Book). Government Research Corporation, Washington, D.C., 1980.

3 I Ball, Robert R., 'Health and social policy for an aging society'. Unpublished paper. University of Texas Health Science Center, Houston TX., I 985 . 'Medicare's success in reducing its own costs. The date for Medicare bankruptcy keeps being postponed. The Congressional Budget Office now says ten years as compared to 1989 or 1990 a short time ago, and if one takes seriously the optimistic economic projections of the 1986 budget estimates, the date would move to sometime in the next century' (Ball, 1985).

32 Wood, J. B., Estes, C. L., Lee, P. R. and Fox, P. J., Public Policy, the Private Nonprofit Sector and the Delivery of Community-Based Long Term Care Services for the Elderly. Final Report, 1983; Year 02 Report, 1984. Aging Health Policy Center, University of California, San Francisco CA., 1983; 1984 .

33 Salamon, L. M. and Abramson, A. J., Nonprofits and the Federal budget: deeper cuts ahead. Foundations News (March/April 1985). 48-54.

34 Starr, P., The Social Transformation of American Medicine. Basic, New York 1982.

35 O'Connor, J., 1984, op. cil.

36 Kuttner, R., The Economic Illusion: False Choices Between Prosperity and Social Justice. Houghton Mifflin, Boston, 1984 .

37 Miller, S. M., Welfare State Revisited. Social Problems (1985), p. 64.

${ }^{8}$ Olson, L. K., The Political Economy of Aging. Columbia University Press, New York 1982 . 